\title{
Chromosomal Aberrations and Sister Chromatid Exchanges in Cultured Human Lymphocytes III. Induced by Ascorbic Acid (Vitamin-C) ${ }^{1}$
}

\author{
Ajay K. Jain and N. Sethi \\ Division of Toxicology, Central Drug Research Institute, Chattar Manzil Palace, \\ Post Box NO. 173, Lucknow-226 001, (U. P.), India
}

Accepted June 6, 1991

The medicinal importance of ascorbic acid (vitamin C) was first demonstrated by James Lind in the mid-18th century when he found that juice of fresh citrus fruit could cure the scurvy. The human body does not synthesize ascorbic acid (Leevine 1986). It is abundantly present in fresh fruits and vegetables. Vitamin $\mathrm{C}$ deficient diet may lead to scurvy and impairment of immune response (Leevine 1986). Szent-Gyorgyi (1928) first isolated it in the pure form. It has been found that empirical formula is $\mathrm{C}_{6} \mathrm{H}_{8} \mathrm{O}_{8}$ and chemically it is enolic form of 3-ketoL-gulofuranlactone:

Because of its broad pharmacological significances, it is widely used singly or in combination with other vitamins and drugs. Its mutagenic potentiality is controversial. Some of the workers have found it to be mutagenic (Stich et al. 1976, 1979, Gut-<smiles>C[C@H](O)[C@@H]1OC(=O)[C@@H]2O[C@@H](O)[C@@H]1O2</smilestenplan 1977, Omura et al. 1978, Galloway and Painter 1979) while others have reported it to be non-mutagenic (Norkus et al. 1983). The present study was therefore undertaken to evaluate its genotoxic effects in cultured human lymphocytes system which will be helpful to determine its genetic hazards to human populations and consequently safe use.

\section{Materials and methods}

The mode of treatment has been described in Part I of this series. Solutions of different concentrations $(0.1,1.0,10.0$ and $100.0 \mu \mathrm{g} / \mathrm{ml})$ were prepared in sterile deionized distilled water by serial dilution method.

\section{Results}

\section{(A) Chromosomal aberrations}

Aberrant metaphases did not show significant variations after both types of treatments (Tables 1, 2). Most common aberration was chromatid gap. Chromosome gap was observed occasionally (Treatment 'A', $1.0 \mu \mathrm{g} / \mathrm{ml}$-Table 1). Aberrant cells did not show multiple aberrations per cell.

(B) Sister chromatid exchanges ( $S C E$ 's)

SCE's per cell were decreased significantly when cells were cultured in presence of 100.0 $\mu \mathrm{g} / \mathrm{ml}$ ascorbic acid (Table 3). Low dose treatment did not significantly alter SCE frequency 
and cell cycle kinetics. Treatment 'B' did not show any effect on SCE frequency and cell cycle (Table 4).

\section{Discussion}

Ames et al. (1973) found ascorbic acid to be a weak mutagen. Later, Stich et al. (1976) found that the treatment of ascorbic acid and $\mathrm{Cu}^{2+}$ caused DNA fragmentation, DNA repair synthesis and chromosome aberrations in cultured human fihroblastic cells. SCE's were elevated in Chinese hamster cells and human lymphocytes exposed to A. A. (Macrae and Stich 1979, Galloway and Painter 1979). Rosin et al. (1980a) found ascorbic acid as a positive mutagen in hypoxanthine guanine phosphoribosyl transferase (HGPRT) gene locus mutation assay in cultured Chinese hamster ovary (CHO) cells. It has been suggested that in presence of $\mathrm{O}_{2}$ and metal ions e.g. $\mathrm{Cu}^{+2}$ ascorbic acid is known to generate $\mathrm{H}_{2} \mathrm{O}_{2}$ and free radicals

Table 1. Chromosomal aberrations after treatment type 'A' of ascorbic acid

\begin{tabular}{|c|c|c|c|c|c|}
\hline \multirow{3}{*}{ Treatment } & \multirow{3}{*}{$\begin{array}{c}\text { No. of } \\
\text { metaphases } \\
\text { scored }\end{array}$} & \multirow{3}{*}{$\begin{array}{c}\text { Aberrant } \\
\text { metaphases } \\
(\%)\end{array}$} & \multirow{3}{*}{$\begin{array}{c}\text { No. of } \\
\text { aberration } \\
\text { per } \\
\text { aberrant } \\
\text { cell }\end{array}$} & \multicolumn{2}{|c|}{ Type of aberrations ( $\%)$} \\
\hline & & & & Chromatid & Chromosome \\
\hline & & & & gap & gap \\
\hline Control & 100 & 1.00 & 1 & 1.0 & 0.0 \\
\hline $0.1 \mu \mathrm{g} / \mathrm{ml}$ & 100 & 1.00 & 1 & 1.0 & 0.0 \\
\hline $1.0 " \prime$ & 100 & 2.00 & 1 & 1.0 & 1.0 \\
\hline $10.0 "$ & 100 & 0.0 & 0 & 0.0 & 0.0 \\
\hline $100.0 " \prime$ & 100 & 1.00 & 1 & 1.0 & 0.0 \\
\hline
\end{tabular}

Table 2. Chromosomal aberrations after treatment type 'B' of ascorbic acid

\begin{tabular}{|c|c|c|c|c|c|}
\hline \multirow{3}{*}{ Treatment } & \multirow{3}{*}{$\begin{array}{l}\text { No. of } \\
\text { metaphases } \\
\text { scored }\end{array}$} & \multirow{3}{*}{$\begin{array}{c}\text { Aberrant } \\
\text { metaphases } \\
(\%)\end{array}$} & \multirow{3}{*}{$\begin{array}{l}\text { No. of } \\
\text { aberration } \\
\text { per } \\
\text { aberrant } \\
\text { cell }\end{array}$} & \multicolumn{2}{|c|}{ Type of aberrations $(\%)$} \\
\hline & & & & Chromatid type & Chromosome type \\
\hline & & & & gap & \\
\hline Control & 100 & 0.0 & 0 & 0.0 & 0.0 \\
\hline $0.1 \mu \mathrm{g} / \mathrm{ml}$ & 100 & 1.0 & 1 & 1.0 & 0.0 \\
\hline $1.0 \quad "$ & 100 & 0.0 & 0 & 0.0 & 0.0 \\
\hline $10.0 " \prime$ & 100 & 2.0 & 1 & 2.0 & 0.0 \\
\hline $100.0 \quad "$ & 100 & 2.0 & 1 & 2.0 & 0.0 \\
\hline
\end{tabular}

derived from $\mathrm{H}_{2} \mathrm{O}_{2}$ (Weissberger and Luvalle 1944, Taqui Khan and Martell 1967) which can damage DNA and other cellular components (Fridovich 1976) and thereby causing mutation, chromosomal aberrations and sister chromatid exchanges (Stich et al. 1976, Morgan et al. 1976). This is further evident by the findings that catalase inhibits the magnitude of different biological end points (Morgan et al. 1976, Stich et al. 1978, Prasad et al. 1978, Rosin et al. 1980a). Several other transition metals $\left(\mathrm{Mn}^{+2}, \mathrm{Fe}^{+2}\right)$ have also been found to enhance the mutagenicity of ascorbate (Stich et al. 1976, 1979). The above studies suggest that the interaction of ascorbic acid and metal ions generate $\mathrm{H}_{2} \mathrm{O}_{2}$ in the incubation mixture and that $\mathrm{H}_{2} \mathrm{O}_{2}$ or the radicals derived from $\mathrm{H}_{2} \mathrm{O}_{2}$ cause damage. Non-generation or scabenging of per oxide radicals dose not allow DNA damage. Contrary to the in vitro results, Speit et al. (1980) observed that treatment with extremely high doses $(200-10,000 \mathrm{mg} / \mathrm{kg} \mathrm{b}$. wt.) of ascorbic acid had no effect on the SCE frequency and cell cycle kinetics in the bone marrow of the Chinese hamster. It has been suggested that this might because in contrast to in vitro conditions, the 

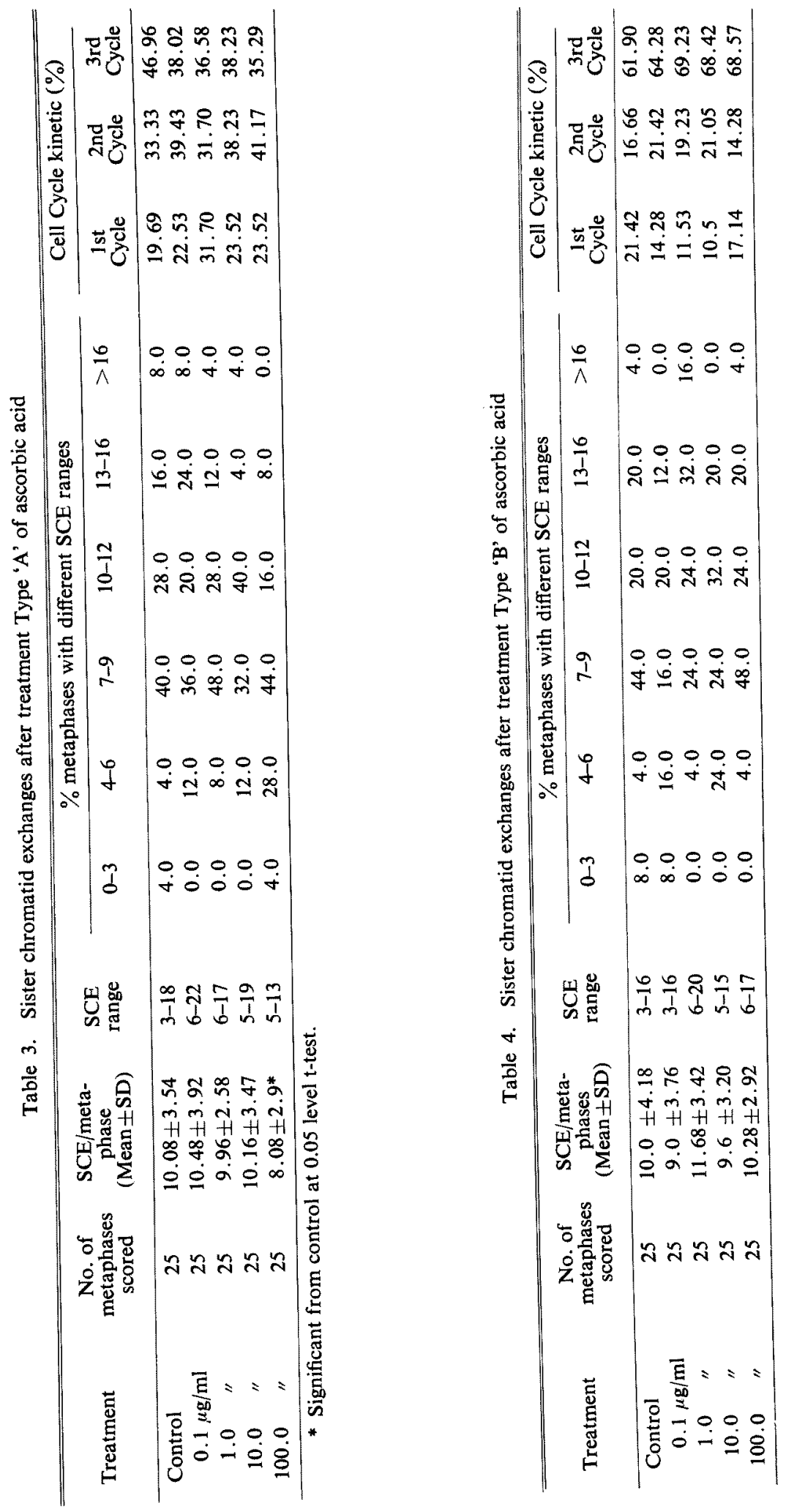
cells in whole mammalian organisms seems well protected against damage by $\mathrm{H}_{2} \mathrm{O}_{2}$ and radicals, since glutathione per oxidase, catalase and super oxide dismutase prevent the destructive action of per oxides and radicals. Thus it seems that if an organism is deficient of these factors, ascorbic acid may cause genetic damage.

In our study the lack of chromosomal aberrations and SCE inducing effect seems due to absence of metal ions because culture medium was prepared in deionized sterile distilled water. Further, significant lowering of SCE's after continuous treatment of $100.0 \mu \mathrm{g} / \mathrm{ml}$ ascorbic acid (Table 3 ) suggests that in absence of metal ions it might have some kind of DNA repair inducing effects resulting in decreased spontaneous SCE frequency. Brief treatment (type ' $B$ ' of $3 \mathrm{hr}$ ) did not appear sufficient to induce these repair process (es). Its DNA repair inducing property is also evident by other in vitro studies (Benedict et al. 1980, Gol Winkler et al. 1980, Rosin et al. 1980b) and in vivo studies (Cameron and Paulling 1978, Sram et al. 1983). Benedict et al. (1980), Gol-Winkler et al. (1980) and Rosin et al. (1980b) found that ascorbic acid suppressed the transformation of $\mathrm{C} 3 \mathrm{H} / 10 \mathrm{~T} 1 / 2$ cells induced by 3 methyl cholanthrene. Cameron and Paulling (1978) noticed that cancer patients treated with ascorbate were found to have a mean survival time of 300 days longer than that of the control. Sram et al. (1983) observed that daily administration of $1.0 \mathrm{~g}$ ascorbic acid to coal tar workers significantly decreased the aberrant metaphases. Thus it is evident that ascorbic acid is potent to induce some kind of DNA repair process (es).

From the present study it can be concluded that ascrobic acid itself is not DNA damaging agent. It can show mutagenic and genotxic activities in presence of metal ions. In absence of metal ions it appears rather DNA repair inducer and enhancer of life expectancy. Our this view gets strengthened by the study of Norkus et al. (1983). In a very sensitive host mediated mutagenicity assay they found that administration of $5000 \mathrm{mg} / \mathrm{kg}$ to guinea pigs did not show mutagenic response to $S$. typhimurium TA 100 . No significant effect on SCE frequency was noticed by Speit et al. (1980) at very high dose $(10,000 \mathrm{mg} / \mathrm{kg} \mathrm{b}$. wt.) in bone marrow cells of Chinese hamster. However, the study of Stich et al. (1980) warns and suggests that combinational preparations of ascorbic acid with iron have clastogenic effects. Therefore, it is stressed to have detailed interaction studies with other drugs so that its toxic effect could be eliminated.

\section{Summary}

Ascorbic acid (A. A.) (vitamin C) is one of the most widely used (singly or in combinations) vitamins. Because of its broad pharmacological significances and presence in natural food products, the present study was carried out to evaluate its cytogenetic effects in in vitro human lymphocytes. Concentrations screened were $0.1,1.0,10.0$ and $100.0 \mu \mathrm{g} / \mathrm{ml}$. Aberrant metaphases did not show significant variation after both types of treatments. $3 \mathrm{hr}$ treatment in $\mathrm{G}_{2}$ /early $\mathrm{S}$ phase did not affect the SCE frequency, while continuous treatment $(100.0 \mu \mathrm{g} /$ $\mathrm{ml}$ ) significantly reduced the same. This suggested that constant presence of A. A. might have potentiality to induce DNA repair. Mutagenic and antimutagenic effects of A. A. have been discussed in detail. From the present study it seems that A. A. itself is not mutagenic but may have mutagenic action in presence of metal ions $\left(e . g . \mathrm{Fe}^{+2}\right)$.

\section{Acknowledgement}

Thanks are due to Council of Scientific and Industrial Research, New Delhi, India for providing financial assistance. 


\section{References}

Ames, B. N., Durston, W., Yamasaki, E. and Lee, P. 1973. Carcinogens are mutagens: A simple test system combining liver homogenates for activation and bacteria for detection. Proc. Natl. Acad. Sci. (U. S. A.) 70: 2281-2285.

Benedict, W. F., Wheatley, W. L. and Jones, P. A. 1980 . Inhibition of chemically induced morphological transformation and reversion of the transformed phenotype of ascorbic acid in $\mathrm{C} 3 \mathrm{H} / 10 \mathrm{~T} 1 / 2$ cells. Cancer Res. 40: 2796-2801.

Cameron, E. and Pauling, L. 1978. Supplemental ascorbate in the supportive treatment of cancer: Re-evaluation of prolongation of survival times in terminal cancer patients. Proc. Natl. Acad. Sci. (U. S. A.) 75: $4538-4542$.

Fridovich, I. 1976. Oxygen radicals, hydrogen per oxide and oxygen toxicity. In W. A. Pryor (Ed.) Free Radicals in Biology, Vol. 1, Academic Press, N. Y., pp. 239-276.

Galloway, S. M. and Painter, R. B. 1979. Vitamin C is positive in the DNA synthesis inhibitions and sister chromatid exchanges tests. Mutat. Res. 60: 321-327.

Gol-Winkler, R., Declerck, Y. and Gielen, J. E. 1980. Ascorbic acid effect on methyl cholanthrene induced transformation in C3H10T $1 / 2$ clone 8 cells. Toxicology $17: 237-239$.

Guttenplan, J. B. 1977. Inhibition by L-ascorbate of bacterial mutagenesis induced by two-N-nitroso compounds. Nature 268: 368-370.

Leevine M. 1986. New concept in the biology and biochemistry of ascorbic acid. New Engl. J. Med. 314: $892-901$.

Macrae, W. D. and Stich, H. F. 1979. Induction of sister chromatid exchanges in Chinese hamster cells by the reducing agents bisulfite and ascorbic acid. Toxicology 13: 167-174.

Morgan, A. R., Cone, R. L. and Elgert, T. M. 1976. The mechanism of DNA strand breakage by vitamin C and super oxide and the protective roles of catalase and super oxide dismutase. Nucl. Acid Res. 3 : 1139-1149.

Norkus, E. P., Kuenzig, W. and Conney, A. H. 1983. Studies on the mutagenic activity of ascorbic acid in vitro and in vivo. Mutat. Res. 117: 183-191.

Omura, H., Shinohara, K., Maeda, H., Nonaka, M. and Murakami, H. 1978. Mutagenic action of triose reductone and ascorbic acid on Salmonella typhimurium TA 100 strain. J. Nutr. Sci. Vitaminol. 24: 185-194.

Parshad, R., Sanford, K. K., Jones, G. M. and Tarone, R. E. 1978. Fluorescent light induced chromosome damage and its prevention in mouse cells in culture. Proc. Natl. Acad. Sci. (U. S. A.) 75 : $1830-1833$.

Rosin, M. P., San, R. H. C. and Stich, H. F. 1980a. Mutagenic activity of ascorbate in mammalian cell cultures. Cancer Lett. 8: 299-305.

- Peterson, A. R. and Stich, H. F. 1980b. The effect of ascorbate on 3-methyl cholanthrene induced cell transformation in C3H 10T 1/2 mouse embryo fibroblast cell cultures. Mutat. Res. 72: 533-537.

Speit, G., Wolf, M. and Volgel, W. 1980. The SCE inducing capacity of vitamin C: Investigations in vitro and in vivo. Mutat. Res. 78: 273-278.

Sram, R. J., Dobias, L., Pastorkova, A., Rossner, P. and Janka, L. 1983. Effect of ascorbic acid prophylaxis on the frequency of chromosome aberrations in the peripheral lymphocytes of coal-tar workers. Mutat. Res. 120: 181-186.

Stich, H. F., Karim, J., Koropatnick, J. and Lo, L. 1976. Mutagenic action of ascorbic acid. Nature 260: $722-724$.

-, Wei, L. and Lam, P. 1978. The need for a mammalian test system for mutagens: Action of some reducing agents. Cancer Lett. 5: 199-204.

-, - and Whiting, R. F. 1979. The enhancing effect of transition metals on chromosome damaging action of ascorbate. Cancer Res. 39: 4145-4151.

-, - and - 1980. Chromosome aberrations in mammalian cells exposed to vitamin $C$ and multiple vitamin pills. Food Cosmet. Toxicol. 18: 497-501.

Szent-Gyorgyi, A. 1928. Observations of the functions of per oxidase systems and the chemistry of adrenal cortex. Biochem. J. 22: 1387-1409.

Taqui Khan, M. M. and Martell, A. E. 1967. Metal ion and metal chelate catalyzed oxidation of ascorbic acid by molecular oxygen I. Cupric and ferric ion catalyzed oxidation. J. Am. Chem. Soc. 89: 41764185 .

Weissberger, A. and Luvalle, J. E. 1944. Oxidation processes XVII. The autoxidation of ascorbic acid in the presence of copper. J. Am. Chem. Soc. 66:700-705. 